\title{
EMIS Information Systems Audit on the Timor-Leste Education Ministry with a COBIT4.1 Framework
}

\author{
Arão Ternorio A. Santos \\ Faculty of Information \\ Technology \\ Satya Wacana Christian \\ University \\ Diponegoro Street, 52-60 \\ Salatiga 50711, Indonesia
}

\author{
Marwata \\ Faculty of Information \\ Technology \\ Satya Wacana Christian \\ University \\ Diponegoro Street, 52-60 \\ Salatiga 50711, Indonesia
}

\author{
Irwan Sembiring \\ Faculty of Information \\ Technology \\ Satya Wacana Christian \\ University \\ Diponegoro Street, 52-60 \\ Salatiga 50711, Indonesia
}

\begin{abstract}
An information system is one of the factors of success of an organization. Using information technology maximally will help stakeholders in providing an optimal policy in an organization. The goal of this research is to find out the management of the EMIS information system reviewed from the COBIT framework and the level of maturity in using the EMIS Information System that is measured with a maturity level. A qualitative research method is used in this research along with statements in the COBIT 4.1 guidelines to analyze the problem deeply. The research results show that the EMIS subdivision has applied procedures that are outlined in the domain of COBIT 4.1, which is proven with the level of managed maturity in the information management process in the four domains, even though this subdivision does not possess controlled standard guidelines in the information processing.
\end{abstract}

\section{Keywords}

Audit, Information Systems, EMIS, IT Governance, COBIT 4.1

\section{INTRODUCTION}

Information Technology (IT) has made rapid developments. IT is a set of instruments that helps users work with information and do tasks that are related with information processing. With the help of IT, work processes that occur in an organization can be done quickly and efficiently. Using IT in an organization can help stakeholders in the decision making process as well as provide significant changes in fixing and developing an organization for the future.

The East Timor Education Ministry or in its official language Ministério da Educação (ME) is a government institution that serves society in the education sector. Education and training are keys to improve opportunities for people's lives, by assisting them to realize their potential. In addition, it is also essential for the growth and development of the East Timor economy [2]. In its service these days, ME utilizes IT to provide solutions and benefits through opportunities as a form of IT strategic role in reaching maximum achievement.

The IT used in ME is under the Information Technology and Statistics, Planning National Directorate or commonly known as DNPETI (Direcção Nasional Plano, Estatistika, Teknologia da Informação). In DNPETI there is an EMIS (Education Management Information System) subdivision, which is a division that processes and provides information for teachers and students until the while school infrastructure in all parts of East Timor. In its development, EMIS started in 2002. The
EMIS data processing system is more developed. In 2008, with the support of international staff provided by UNICEF, the data processing system is computerized and has started to be integrated with other ministries in East Timor. EMIS has an important role in ME, development partners, and society in general, because its use provides information service for education development in East Timor. However, in developing its use, it has not been examined in detail the maturity of information technology management in the information processing of EMIS at this time. Therefore, there needs to be a total evaluation to find out the maturity of the present information technology management processes in this subdivision.

The evaluation that is done is for information system auditing. Information system auditing is a fact evaluation and gathering process to determine whether the computer system being used can protect the assets of an organization, is able to protect data integrity, can help reach organizational goals effectively, and use its resources efficiently [3].

To obtain maximal information system auditing results, there needs to be guidelines that serve as the basis to achieve organizational goals. COBIT (Control Objectives for Information and Related Technology) is an IT management standard that was developed by the IT Governance Institute (ITGI), which is an organization that conducts studies about IT management models based in the United States. COBIT has a number of best practices documentation for IT governance that can help auditors, management, and users to bridge the gap between business risks, control needs, and technical problems [4].

This research is based on previous research, called The Measurement of Information Technology Performance in Indonesian Higher Education Institutions in the Context of Achieving Institution Business Goals Using the Cobit Framework Version 4.1 [5]. The research discusses measuring IT work performance to achieve business goals by measuring the level of maturity in the IT process using the COBIT framework model version 4.1. The goal of this research is to examine the IT management and provide recommendations for improvement in IT processing for the service process for stakeholders, so that it can reduce the chance for potential risks in the future. A descriptive research method is used, meaning that the research results are provided in a descriptive form, whether it is qualitative or quantitative descriptive. The research results show that IT has been managed well, as the IT process supports business goals, which are already standardized, documented, and communicated well. However, 
for the service aspect for users, there has to be a higher priority for improving the Information System and Technology Bureau (BTSI), because this aspect has the worst work performance among the other aspects of the business goals.

Next, research entitled An Evaluation of Information Technology Management Using a Cobit Work Framework to Support the Academic Information System Service [6]. The research discusses an evaluation of information technology management in providing academic information system service at Budi Luhur University using COBIT 4.0 IT management standards, which are limited to the delivery \& support (DS) domain and the monitoring \& evaluation (ME) domain. The goal of this research is to optimize the quality of academic information system service at Budi Luhur University and to discover the level of harmony in the IT strategy plan with the organizational business strategies that have been established. The method used is a COBIT 4.0 framework while modeling maturity with maturity level. The research results reveal that the level of maturity in the academic information system service of IT management at Budi Luhur University in the delivery \& support domain and the monitoring \& evaluation domain are unsatisfactory because it is at the 2-repeatable but intuitive level, so that the research hypothesis is accepted.

From the previous research results, the researchers used a COBIT framework in managing the risks and achieving the business goals. With various methods to acquire data, the results are in the form of findings and recommendations in measuring the maturity level according to the standard operation procedures (SOP) that have been applied. This is a basis for the researcher to study the EMIS information system management while measuring the maturity of the information system and model additions in IT management of EMIS according to COBIT 4.1 framework standards.

\section{LITERATURE REVIEW}

\subsection{Information System}

An information system (IS) is a combination of information technology and human activity that uses the technology to support its operation and management. In general terms, the term information system that is often used refers to interactions between people, algorithmic processes, data, and technology. With this understanding, this term is not only used to refer to communication and information technology (TIK) organization usage, but also the way people interact with this technology in supporting the business process [7]. An information system is a system in an organization that unites daily transaction processing needs, supports operations, is managerial and strategic in an organization, and provides a certain outside party with necessary reports [8].

\subsection{Audit Information System}

An audit is the process of collecting and evaluating evidence to determine whether a computer system safeguards assets, maintains data integrity, achieves organizational goals effectively, and uses consumer resources efficiently [3]. Auditing should be done by an independent and competent party. Auditing is a logical, structured, and organized step or procedure. Auditing is done with planned steps, is organized, and has a goal to obtain and evaluate evidence objectively. This means in gathering evidence, a certain systematic process is needed to evaluate without being partial or prejudiced towards the evidence [9].

\subsection{IT Governance}

It is an integral part of enterprise governance and consists of the leadership and organizational structures and processes to ensure that the organization sustains and extends its strategy and objectives. The IT Governance Institute specifies the decision rights and accountability framework to encourage desirable behavior in the use of IT [10].

The primary goal of IT governance is to confirm that investing in IT produces a business value and reduces risks related with IT. IT governance is needed to confirm investing in producing value and reducing risks related with IT, and avoiding failure when IT is devised to bring changes in an organization [10].

The IT Governance Institute (ITGI) is supported by CISA certified practitioners, who are also book authors and references for this research. In 2007, a framework was issued to measure IT management in an organization called COBIT 4.1[4]. Besides the COBIT framework, a maturity level was also provided to measure the maturity of IT management in an organization. Effective IT governance can answer the following three questions:

1. What decisions have to be taken to ensure that effective management and IT use is conducted?

2. Who has to make decisions related with using IT?

3. How are these decisions made and monitored?

From these questions, a certain scheme can be depicted to help understand, design, communicate, and foster effective IT governance as follows:

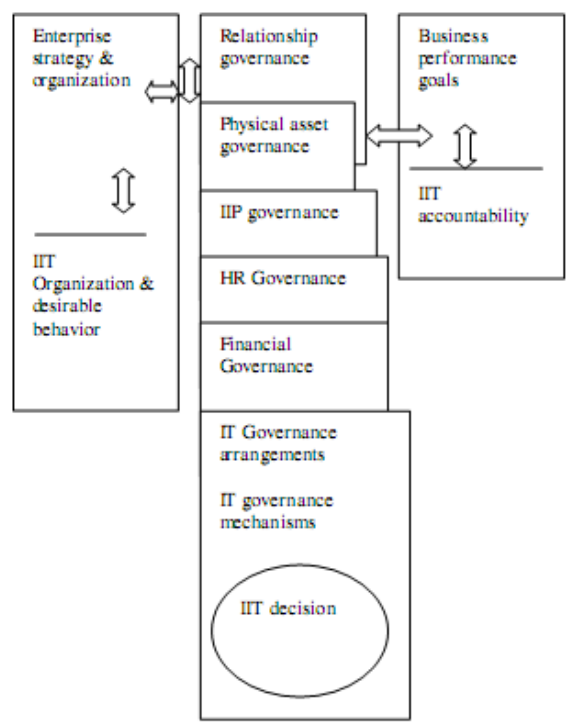

Figure 1. Effective IT Governance

Based on Figure 1, in developing effective IT governance, the following things are needed [11]:

- To establish better organizational strategies.

- To pay attention to organizational behavior as well as how to apply IT in the organization.

- To arrange the six assets well that are owned by an organization like: relationships between assets, physical assets, intellectual property assets, human relation assets, financial assets, and IT.

To create good organizational strategies related with IT usage in an organization.

\subsection{COBIT 4.1}

COBIT consists of technology evaluation instruments that 
mostly deal with primary standards that in general are accepted worldwide related to control and technology. In its development, COBIT has standards from the International Organization for Standardization (ISO); Electronic Data Interchange for Administration, Commerce, and Trade (EDIFACT); Council of Europe, Organization for Economic Cooperation and Development (OECD); ISACA; Information Technology Security Evaluation Criteria (ITSEC); Trusted Computer Security Evaluation Criteria (TCSEC); Committee of Sponsoring Organizations of the Treadway Commission (COSO); and National Institute of Standards and Technology (NITS) [12]. COBIT has a vision as a model for IT mastery, while its mission is to conduct research, develop, publish, and promote a collection of controls on information technology that is authoritative, up-to-date, and accepted internationally for business manager and auditor needs [13].

The goal of COBIT is to provide clear policies and good training for IT governance for organizations all over the world to help senior management understand and manage risks that are related with information technology. COBIT does this by providing an IT governance work framework and detailed objective control guidelines for management, business process owners, users, and auditors [14]. An IT management control framework identifies the reasons why IT management is needed, the importance of stakeholders, and what is needed to finish it.

In providing information to the business world according to the business and information technology management needs, the COBIT process model has four domains which comprise 34 processes and 318 control objectives, along with 1,547 control practices. Therefore, the domain can be identified as having 34 processes [4].

The COBIT work framework consists of high level control goals and classified structures in general, which basically consist of three IT management business levels regarding IT resource management. From below, the activities and tasks are those which are done separately and needed to achieve results that can be measured. Next, activities and tasks are grouped in the IT process. The IT processes that have the same IT management problems will be grouped in a domain. Then the work framework concept can be seen from three viewpoints: information criteria, IT resources, and IT processes, like what can be seen in the following figure:

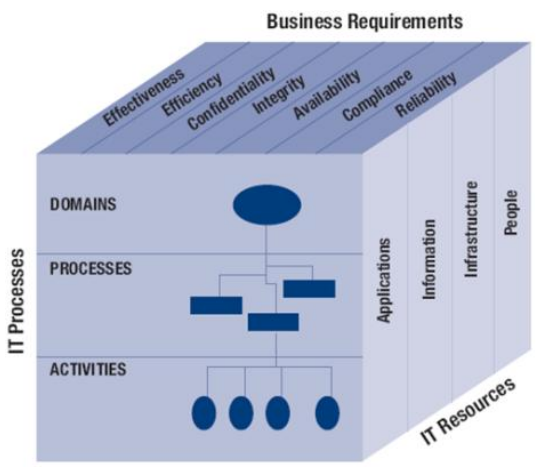

Figure 2. COBIT Framework

\subsection{Maturity Model}

A maturity model is a method to measure the level of process management development, which means to measure the extent of the management capability. How good the management capability and development is depends on reaching its business goals. The Maturity Model to control the IT process consists of developing an evaluation method, so that an organization can evaluate itself from non-existent conditions to optimized conditions $(0-5)$. For every IT process, there is a measuring scale with levels, based on a " 0 " rating to a " 5 " rating. This scale is related with a description of the qualitative maturity model that ranges from "non-existent" to "optimized" [13], as seen in Figure 3.

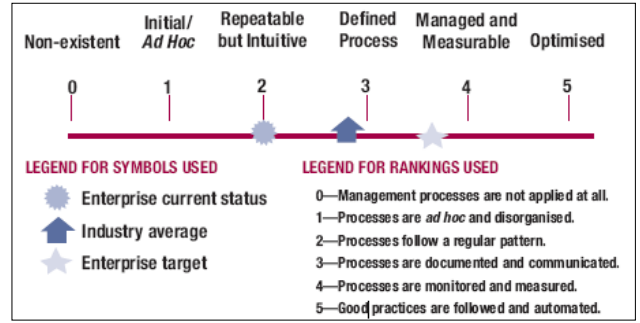

Figure 3. Maturity Model

From the Maturity Model, it reveals the level of IT management ability in the maturity scale that is divided into 6 levels, which are shown in the following table.

Table 1. Maturity Level

\begin{tabular}{|c|c|c|}
\hline Level & Category & Criteria \\
\hline 1 & Non-existent & $\begin{array}{l}\text { There is no process. The } \\
\text { organization is unaware it has a } \\
\text { problem that needs to be managed. }\end{array}$ \\
\hline 2 & Adhoc & $\begin{array}{l}\text { There is proof that an organization } \\
\text { realizes it has a problem that needs } \\
\text { to be managed. However, there is } \\
\text { no standard process, so it has to be } \\
\text { managed with an ad hoc } \\
\text { characteristic that is applied on a } \\
\text { case by case basis. There is no } \\
\text { process management organization. }\end{array}$ \\
\hline 3 & Repeatable & $\begin{array}{l}\text { The process has a pattern that is } \\
\text { followed by all those who do it. } \\
\text { There is no training or } \\
\text { establishment of standard } \\
\text { procedures formally, and the } \\
\text { obligations to follow them are } \\
\text { handed over to each party. It still } \\
\text { relies on individual knowledge, so } \\
\text { there is low consistency. }\end{array}$ \\
\hline 4 & Defined & $\begin{array}{l}\text { The procedures that originate from } \\
\text { habits are made as part of the } \\
\text { standards and put into document } \\
\text { form as well as socialized through } \\
\text { training. There is an obligation to } \\
\text { carry it out, but there is no } \\
\text { supervision to determine deviations } \\
\text { in conducting it. }\end{array}$ \\
\hline 5 & Managed & $\begin{array}{l}\text { Management oversees adherence to } \\
\text { it being carried out and intervenes if } \\
\text { there is a problem in its } \\
\text { implementation. The process is } \\
\text { continually perfected. }\end{array}$ \\
\hline
\end{tabular}

\section{RESEARCH METHODOLOGY}

This research is conducted using a qualitative method, which is a research method that is based on a post-positivism philosophy, used to research an object's natural condition where the researcher is a key instrument, taking source samples with data taken purposively. The data gathering technique is done by combining inductive/qualitative data 
analyses, and the qualitative research results stress more on meaning than generalization [15]. With a qualitative research method accompanied with questions in the Cobit 4.1 guidelines, the problem will undergo an in-depth analysis. Qualitative research functions to provide substantive category and qualitative research hypothesis. With a qualitative method, the data obtained is more complete, more in-depth, credible, and meaningful, so that the research goals can be reached.

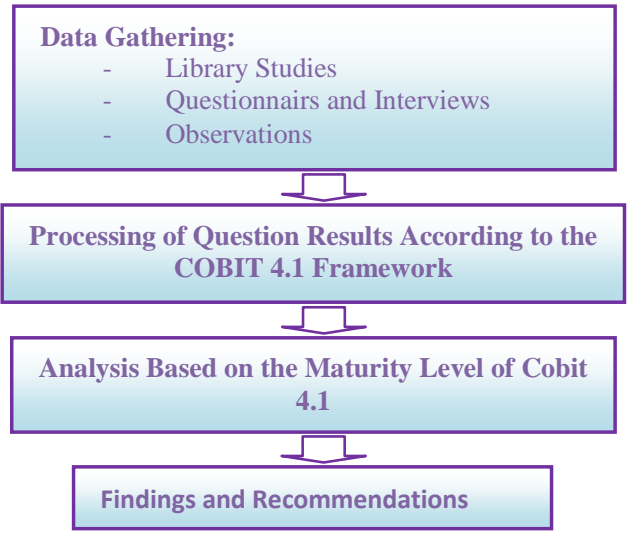

Figure 4. Problem Solving Steps

The process in gathering the data in the IT management of EMIS IS through library studies that is done includes searching for literature from books, media, experts, or other research results about the Cobit framework, auditing, information systems, and the EMIS information system that functions to arrange theoretical foundations that are used in conducting research. Interviews are conducted on 23 respondents that consist of international assessors, national assessors, department chiefs, and EMIS IT or non-IT functionaries that are a subdivision of DNPETI, based on the RACI (responsible, accountable, consulted, and informed) table, which is those parties who have a vested interest in the IT management of an organization in the data processing process [13].

The instrument used in the interviews is questionnaires, which are designed through question extraction that is outlined in COBIT 4.1. The data from the Questionnaire Statement results is processed based on the Cobit 4.1 framework. The data is grouped based on each domain. Each domain is determined by its level of average values. Next, the relationships are examined between level of value and absolute value, which is adjusted by measuring a likert scale on the maturity level.

After the observation process, interviews, and data analysis, proof can be taken to improve the IT management of EMIS in processing and providing good information in the future, weaknesses, and strengths in EMIS, which will be summarized in a finding and recommended in a good IT management process that will be conveyed to $\mathrm{ME}$ stakeholders

\section{ANALYSIS}

\subsection{Plan and Organize Domain Analysis}

The plan and organize domain involves strategies and tactics, regarding the identification of using the best IT, where it can contribute to the business reaching its goals. The realization of a strategic vision needs to be planned, communicated, and managed for different perspectives. The proper organization as well as technology infrastructure must be put in its place
[13].

The EMIS plan and organize domain can be seen from the questionnaire statement results that are revealed in the following table.

Table 2. Plan and Organize Domain Index

\begin{tabular}{|c|c|c|c|c|}
\hline Statement & $\begin{array}{l}\text { Response } \\
\text { (B) }\end{array}$ & $\begin{array}{l}\text { Statement } \\
\text { Value }\end{array}$ & $\begin{array}{c}\text { Total } \\
\text { Value } \\
\text { (A) }\end{array}$ & $\begin{array}{l}\text { Index } \\
(\mathrm{A} / \mathrm{B})\end{array}$ \\
\hline Strongly Agree & 207 & 5 & 1035 & \multirow{6}{*}{4.23} \\
\hline Agree & 180 & 4 & 720 & \\
\hline Neutral & 54 & 3 & 162 & \\
\hline Do Not Agree & 9 & 2 & 18 & \\
\hline $\begin{array}{l}\text { Strongly } \\
\text { Disagree }\end{array}$ & 10 & 1 & 10 & \\
\hline & 460 & & 1945 & \\
\hline
\end{tabular}

From the PO domain data processing results that are obtained from the COBIT 4.1 question extraction that is modified in accordance with the EMIS business goals, the PO domain maturity in EMIS can be determined. The maturity index value of this domain is obtained from the question value total with the respondent answer total. From this operation, there is a PO domain result with a 4.23 maturity index value. Based on the maturity model level of mapping, the maturity level of the PO domain in EMIS is at level 4.

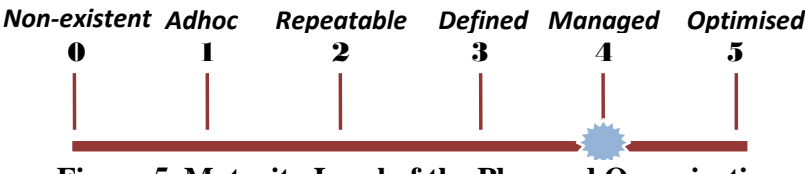

Figure 5. Maturity Level of the Plan and Organization Domain

Based on Figure 5 above, according with the COBIT 4.1 management guidelines that are the basis in reaching the goals of a business, and the maturity level in measuring to what extent there is management credibility, it can be concluded that according to the ranking of a " 0 " rating until " 5 " rating from a non-existent condition until an optimized condition, the plan and organization of EMIS has a 4 rating, which means it is in a managed condition.

This is proven with a feasibility study and findings in the field in the EMIS division, where the DNPETI CEO has made a strategic plan involving the strategies and tactics in using:

- Applications that are able to answer EMIS needs.

- Information that is accurate, relevant, and up-to-date.

- Infrastructure that supports the information processing process, starting from hardware (input/output instruments), software (operation system, EMIS application and its utilities), and its building for EMIS

- Human resources as users from the system that have to possess knowledge in information processing.

This is strengthened with interviews that are conducted on the EMIS staff heads that state EMIS application renewals have been summarized in the ME ministry strategic planning. The strategies and tactics in the ME ministry are adjusted with the vision of EMIS, which is as a data source for the ME ministry and Parceiros Desenvolvimento, where the EMIS vision has been planned and outlined in a detailed (architectural) work framework about an effective EMIS data processing process in the form of a blueprint. The planning that has been conducted by this division has been communicated through 
staff meetings and technology infrastructure. It has been put in its place, where from the teacher, student, as well as school infrastructure data processing have been applied in the database, processed, and the report results have been used in $\mathrm{ME}$ and its education building partners until now. However, from the overall process that has been done, there are still deficiencies like in fostering the application and its utilities, expert staff in the field, and education staff that are still below standards.

The average results from every plan and organization question statement that are measured by maturity level are displayed in the following table.

Table 3. Plan and Organize Domain with Maturity Level

\begin{tabular}{|l|c|c|}
\hline \multicolumn{1}{|c|}{ Sub-Domain PO } & Averages & $\begin{array}{l}\text { Maturity } \\
\text { Level }\end{array}$ \\
\hline PO1. Define a Strategic IT Plan & 4.6 & Optimised \\
\hline $\begin{array}{l}\text { PO2. Define the Information } \\
\text { Architecture }\end{array}$ & 4.35 & Managed \\
\hline $\begin{array}{l}\text { PO3. Determine Technological } \\
\text { Direction }\end{array}$ & 4.3 & Managed \\
\hline $\begin{array}{l}\text { PO4. Define the IT Processes, } \\
\text { Organisation and Relationships }\end{array}$ & 4.45 & Managed \\
\hline $\begin{array}{l}\text { PO5. Manage the IT Investment } \\
\text { PO6. Communicate Management } \\
\text { Aims and Direction }\end{array}$ & 4.2 & Managed \\
\hline $\begin{array}{l}\text { PO7. Manage IT Human } \\
\text { Resources }\end{array}$ & 4.2 & Managed \\
\hline PO8. Manage Quality & 4.2 & Managed \\
\hline PO9. Assess and Manage IT Risks & 4.15 & Managed \\
\hline PO10. Manage Projects & 4.35 & Managed \\
\hline
\end{tabular}

The results of the plan and organization sub-domain averages can be seen in the figure below.

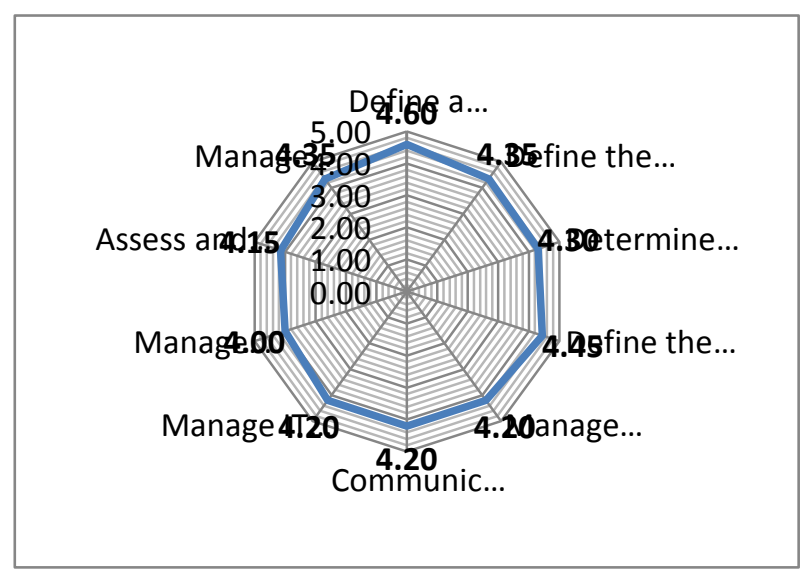

Figure 6. A Representation of the Plan and Organization Domain Analysis Results

\subsection{An Analysis of the Acquire and Implement Domain}

To actualize IT strategies, IT solutions need to be identified, developed or obtain, as well as implemented and integrated within a business process. In addition, the changes and fostering of the system are included in the domain to ensure a continual solution to fulfill business goals [13].

The acquire and implement domain that is used in EMIS can be seen from the results of the questionnaire statement averages that are outlined in the following table.

Table 4. Index of Acquire And Implement Domain

\begin{tabular}{|c|c|c|c|c|}
\hline Statement & $\begin{array}{l}\text { Response } \\
\text { (B) }\end{array}$ & $\begin{array}{l}\text { Statement } \\
\text { Value }\end{array}$ & $\begin{array}{c}\text { Total } \\
\text { Value } \\
\text { (A) }\end{array}$ & $\begin{array}{l}\text { Index } \\
(\mathrm{A} / \mathrm{B})\end{array}$ \\
\hline Strongly Agree & 150 & 5 & 750 & \multirow{6}{*}{4.24} \\
\hline Agree & 114 & 4 & 456 & \\
\hline Neutral & 46 & 3 & 138 & \\
\hline Do Not Agree & 9 & 2 & 18 & \\
\hline \multirow[t]{2}{*}{$\begin{array}{l}\text { Strongly } \\
\text { Disagree }\end{array}$} & 3 & 1 & 3 & \\
\hline & 322 & & 1365 & \\
\hline
\end{tabular}

From the AI domain data processing results that are obtained from COBIT 4.1 statement extractions that are adjusted with the EMIS business goals, the AI domain maturity in EMIS can be determined. The index value of this domain maturity is obtained from the statement value total sub-division results with number of respondent answers. From this operation, AI domain results are obtained with a maturity index value of 4.24. Based on the mapping of the maturity model level, the maturity value of the AI domain in EMIS is at level 4.

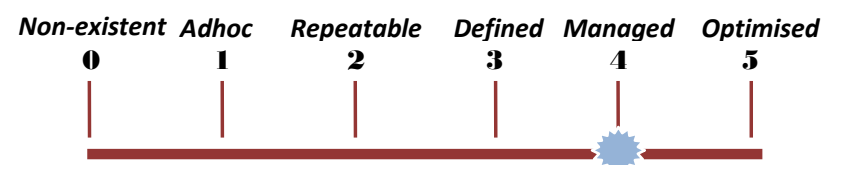

Figure 7. Maturity Level in the Acquire and Implement Domain

Based on Figure 7 above, according to the COBIT 4.1 management guidelines that are the basis in reaching the goals of a business, and the maturity level in measuring to what extent there is management capability, it can be concluded that according to the ranking of a " 0 " until " 5 " rating, meaning from a non-existent condition until an optimized condition, the acquire and implement domain used in EMIS has a rating of 4 , which means it is in a managed condition.

This is proven with findings in the field in the EMIS subdivision, where the results from the problem that has been identified and done with a feasibility study that is adjusted with the information processing in the field. Related to this, the EMIS CEO always conducts staff meetings every month to discuss developments and problems found in information processing like:

- Using the EMIS application and its utilities.

- Using the information processing process, starting from data input, process, until information reports.

- Using hardware like CPU, storage, input/output instruments, and data communication media.

- Using staff work performance for time consistency and discipline.

The results of the staff meeting are given to the DNPETI CEO or international advisors to find a solution to reach the EMIS goals in information service and follow the blueprint that has been established. From the observations, it shows that the heads of EMIS and IT staff always work in coordination to identify risks and problems in updating needed interfaces, 
databases, and information reports. Nevertheless, from all of the processes that have been done, there are still deficiencies like applications that do not answer EMIS needs, the lack of staff awareness in tasks assigned, and time consistency.

The average results from every acquire and implement domain statement that are measured with the maturity level are displayed in the following table.

Table 5. The Acquire and Implement Domain with Maturity Level

\begin{tabular}{|l|c|c|}
\hline \multicolumn{1}{|c|}{ Sub-Domain AI } & Averages & $\begin{array}{c}\text { Maturity } \\
\text { Level }\end{array}$ \\
\hline AI1. Identify Automated Solutions & 4.6 & Optimised \\
\hline $\begin{array}{l}\text { AI2. Acquire and Maintain } \\
\text { Application Software }\end{array}$ & 4.2 & Defined \\
\hline $\begin{array}{l}\text { AI3. Acquire and Maintain } \\
\text { Technology Infrastructure }\end{array}$ & 4.3 & Defined \\
\hline AI4. Enable Operation and Use & 4.35 & Defined \\
\hline AI5. Procure IT Resources & 4.15 & Defined \\
\hline AI6. Manage Changes & 4 & Defined \\
\hline $\begin{array}{l}\text { AI7. Install and Accredit Solutions } \\
\text { and Changes }\end{array}$ & 4.4 & Defined \\
\hline
\end{tabular}

The results of the acquire and implement domain averages can be seen in the following figure.

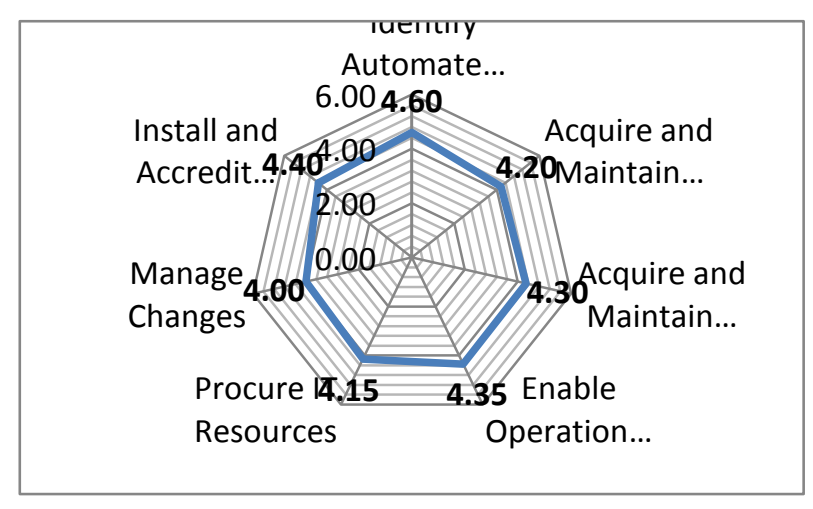

Figure 8. Representation of Acquire and Implement Domain Analytical Results

\subsection{Deliver and Support Domain Analysis}

This domain is related with actual sending from the needed services, which include service, continuity and safety management, user service support, data management, and operational facilities [13].

The deliver and support domain that is operating in EMIS can be seen from the questionnaire statement average results that are displayed in the following table.
Table 6. Deliver And Support Domain Index

\begin{tabular}{|c|c|c|c|c|}
\hline Statement & $\begin{array}{c}\text { Response } \\
\text { (B) }\end{array}$ & $\begin{array}{c}\text { Statement } \\
\text { Value }\end{array}$ & $\begin{array}{c}\text { Total } \\
\text { Value } \\
\text { (A) }\end{array}$ & $\begin{array}{l}\text { Index } \\
\text { (A/B) }\end{array}$ \\
\hline Strongly Agree & 270 & 5 & 1350 & \multirow{6}{*}{4.23} \\
\hline Agree & 226 & 4 & 904 & \\
\hline Neutral & 81 & 3 & 243 & \\
\hline Do Not Agree & 14 & 2 & 28 & \\
\hline \multirow[t]{2}{*}{$\begin{array}{l}\text { Strongly } \\
\text { Disagree }\end{array}$} & 7 & 1 & 7 & \\
\hline & 598 & & 2532 & \\
\hline
\end{tabular}

From the DS domain data processing results that are obtained from COBIT 4.1 statement extractions that are adjusted with the EMIS business goals, the DS domain maturity in EMIS can be determined. The maturity index value of this domain is obtained from the statement value total sub-division results with the respondent answer totals. From this operation, the DS domain results are found with a maturity index value of 4.23 . Based on the mapping of the maturity model level, the maturity value of the DS domain in EMIS is at level 4.

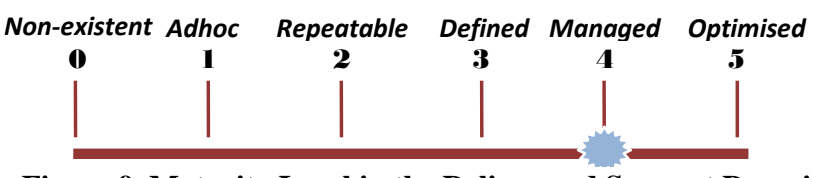

Figure 9. Maturity Level in the Deliver and Support Domain

Based on Figure 9 above, it is in accordance with the COBIT 4.1 management guidelines that are a basis in reaching the goals of a business, and the maturity level in measuring the extent of management capability, it can be concluded that it is in line with the ranking from a " 0 " rating until a " 5 " rating, meaning it is from a non-existent condition to an optimized condition. Therefore, the deliver and support domain in EMIS has a rating of 4 , which means it is in a managed condition.

This is proven with the existence of findings from the field in the EMIS subdivision, where the feasibility study of EMIS IS that has been in operation to provide information to teachers, students, and infrastructure will become a source of information about education development in East Timor. The identification of problems and solutions that are found in the field are then done with support to achieve optimal information results. Related to this, the EMIS staff heads and supervisors always give support to staff when there is a misunderstanding about inputting data, processing, and facilities that support information processing. The system integration in EMIS at this time reduces the operational costs and staff workforce. To protect data confidentiality and integrity, there are limitations in rights to access for users, including the CEO, suppliers, EMIS sub-division staff heads, supervisors, staff, and ministry that are integrated within EMIS. Problem identification, weaknesses, and continual supervision are measuring sticks for EMIS CIO who work in coordination with international staff that are supported by the World Bank and UNICEF for the development of good EMIS in the future. However, from all the processes that have been conducted, there are still deficiencies like fostering the EMIS application and its utilities, software originality, and staff education that are not up to standards.

The average results of every statement in the deliver and support domain that are measured with the maturity level are shown in the following table. 
Table 7. Domain Deliver and Support dengan Maturity Level

\begin{tabular}{|l|c|c|}
\hline \multicolumn{1}{|c|}{ Sub-Domain DS } & Averages & $\begin{array}{l}\text { Maturity } \\
\text { Level }\end{array}$ \\
\hline $\begin{array}{l}\text { DS1 Define and Manage Service } \\
\text { Levels }\end{array}$ & 4.3 & Managed \\
\hline DS2 Manage Third-party Services & 4.25 & Managed \\
\hline $\begin{array}{l}\text { DS3 Manage Performance and } \\
\text { Capacity }\end{array}$ & 4.15 & Managed \\
\hline DS4 Ensure Continuous Service & 4.6 & Optimise \\
\hline DS5 Ensure Sistems Security & 4.25 & Managed \\
\hline DS6 Identify and Allocate Costs & 4.15 & Managed \\
\hline DS7 Educate and Train Users & 4.35 & Managed \\
\hline $\begin{array}{l}\text { DS8 Manage Service Desk and } \\
\text { Incident }\end{array}$ & 4.3 & Managed \\
\hline DS9 Manage the Configuration & 4.2 & Managed \\
\hline DS10 Manage Problems & 4.3 & Managed \\
\hline DS11 Manage Data & 4.25 & Managed \\
\hline $\begin{array}{l}\text { DS12 Manage the Physical } \\
\text { Environment }\end{array}$ & 4.1 & Managed \\
\hline DS13 Manage Operations & 4.35 & Managed \\
\hline
\end{tabular}

The average results of the deliver and support sub-domain can be seen in the following figure.

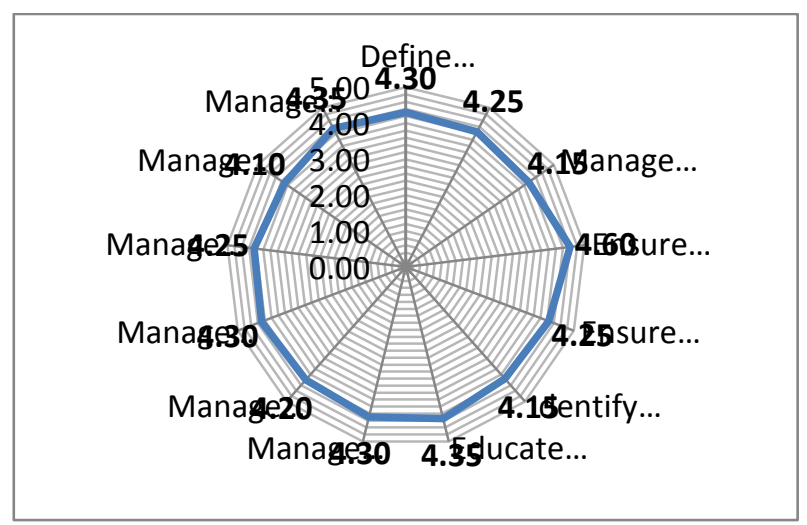

Figure 10. Representation of Deliver and Support Domain Analytical Results

\subsection{Monitor and Evaluate Domain Analysis}

This domain covers an organized evaluation of the IT process from time to time for quality and to fulfill control conditions. This domain discusses work performance management, internal control monitoring, adherence to regulations, and management [13].

The monitor and evaluate domain that is used in EMIS can be seen from the questionnaire statement average results that are displayed in the following table.
Table 8. Monitor and Evaluate Domain Index

\begin{tabular}{|c|c|c|c|c|}
\hline Statement & $\begin{array}{l}\text { Response } \\
\text { (B) }\end{array}$ & $\begin{array}{l}\text { Statement } \\
\text { Value }\end{array}$ & $\begin{array}{c}\text { Total } \\
\text { Value } \\
\text { (A) }\end{array}$ & $\begin{array}{l}\text { Index } \\
\text { (A/B) }\end{array}$ \\
\hline Strongly Agree & 92 & 5 & 460 & \multirow{6}{*}{4.42} \\
\hline Agree & 79 & 4 & 316 & \\
\hline Neutral & 11 & 3 & 33 & \\
\hline Do Not Agree & 2 & 2 & 4 & \\
\hline $\begin{array}{l}\text { Strongly } \\
\text { Disagree }\end{array}$ & 0 & 1 & 0 & \\
\hline & 184 & & 813 & \\
\hline
\end{tabular}

From the ME domain data processing results that are obtained from COBIT 4.1 statement extractions that are adjusted with EMIS business goals, the ME domain maturity within EMIS can be determined. The maturity index value of this domain can be seen from the statement value total sub-division results with the respondent answer totals. From its operation, there are ME domain results with a maturity index value of 4.42 .

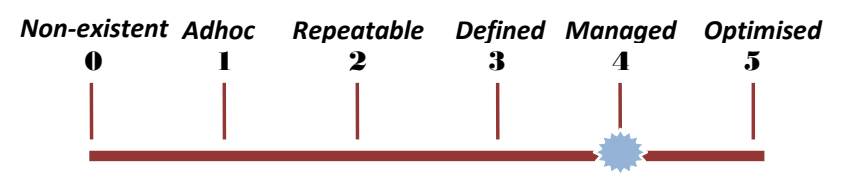

Figure 11. Maturity Level in the Monitor and Evaluate Domain

Based on Figure 11 above, in accordance with the COBIT 4.1 management guidelines that are a basis in reaching business goals, and the maturity level in measuring the extent of management capability, it can be concluded that according to the ranking from a "0" rating until a "5" rating, meaning from a non-existent condition to an optimized condition, the monitor and evaluate domain in EMIS has a rating of 4, which means it has a managed condition.

This is proven with the presence of findings in the field in the EMIS division, where the CIO and all the IT staff continuously provide observation and evaluation of the applications that process information, IT infrastructure that is used to support information processing, along with the staff work performance. Studies and risk identification in EMIS are the basis for CIOs to take real actions to improve visible weaknesses. Related with this, the blueprint that has been established facilitates CIOs and CEOs to control the work performance of staff, and with the weaknesses in the blueprint, it can be revised to become a maximal SOP. This is proven with achieving maximum information results that are done by staff and information that is needed and can be obtained effectively. However, from all of the processes that have been conducted, there are still weaknesses, like there is not an internal auditor in EMIS, and there are no standard guidelines in monitoring jobs or application usage.

The average results of all monitor and evaluate domain statements that are measured with the maturity level are revealed in the following table. 
Table 9. Monitor and Evaluate Domain with Maturity Level

\begin{tabular}{|l|r|l|}
\hline \multicolumn{1}{|c|}{ Sub-Domain ME } & Averages & $\begin{array}{c}\text { Maturity } \\
\text { Level }\end{array}$ \\
\hline $\begin{array}{l}\text { ME1. Monitor and Evaluate IT } \\
\text { Performance }\end{array}$ & 4.55 & Optimised \\
\hline $\begin{array}{l}\text { ME2. Monitor and Evaluate } \\
\text { Internal Control }\end{array}$ & 4.35 & Defined \\
\hline $\begin{array}{l}\text { ME3. Ensure Compliance With } \\
\text { External Requirements }\end{array}$ & 4.35 & Defined \\
\hline ME4. Provide IT Governance & 4.5 & Defined \\
\hline
\end{tabular}

The monitor and evaluate sub-domain average results can be seen in the following figure

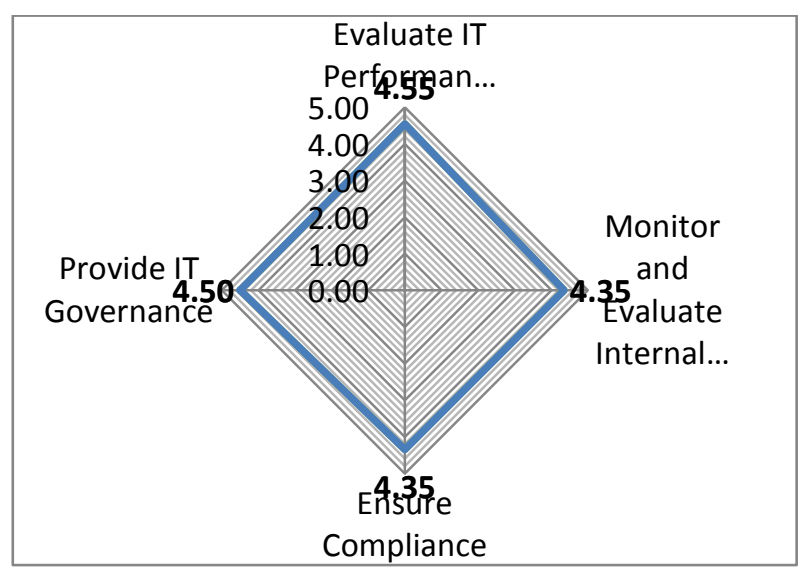

Figure 12. Representation of Monitor and Evaluate Domain Analytical Results

\subsection{COBIT 4.1 in the EMIS Sub-Division}

Using COBIT as an IT control instrument greatly helps an organization to understand and manage risks, as well as evaluate activities that are related with IT. By having COBIT guidelines, it assists stakeholders to make policies and decisions on IT processing that are effective and efficient.

In reaching the goal of having information results that match the needs, ME needs to invest, manage, and control IT resources using a set of structured processes to provide the information service that is needed by a company. Controlling the processing process and providing information for the DNPETI and especially the EMIS subdivision formally does not apply the COBIT 4.1 framework guidelines in managing the activities in processing the available information. This is based on observations and interviews conducted on:

- EMIS division staff heads who admit there has to be a standard control system that can manage the activities in EMIS.

- EMIS division staff heads who claim there should be an effective and efficient application system in processing EMIS IS.

- Data entry staff supervisors state investments are needed for training of staff and experts in the field.

- IT staff heads state human resources are insufficient, and there is a lack of awareness for time consistency.

- International advisors state those who use an EMIS data processing application should make it in accordance with expected needs.

- There is no DNPETI internal auditor who provides an evaluation of activities that are done in EMIS.
However, in the application of DNPETI in managing risks in EMIS, indirectly EMIS already applies SOP that are found in COBIT 4.1. This is proven by processing results and field observations which show that:

- The control objective in the four domains: planning \& organization, acquisition \& implementation, delivery \& support, and monitoring \& evaluating are in a managed condition that shows averages from the four domains that have been carried out.

- There have been observations from EMIS CEOs to control EMIS IS processing activities, although it is not maximal.

In understanding the proof in EMIS at this time, the ME ministry needs to apply a COBIT 4.1 work framework as standard guidelines in managing risks and answering information processing problems to reach goals for information sources. By having this work framework, it provides clear policies in decision making, good training for ME IT governance, and assistance for senior management to understand and handle risks that are related with information technology.

\subsection{Findings and Recommendations}

Based on interview results, observations, and data analytical results that are adapted to the COBIT 4.1 framework, the findings reveal facts related to the application of regulations that are appropriate and others that still need to be altered to achieve information source goals. The findings reveal the appropriate regulations with the sub-domains in the COBIT 4.1 framework are as follows:

To reach the maximum goals with the assistance of COBIT 4.1 guidelines, there are things that need to be improved in EMIS, which are as follows:

Table 10. Findings in the EMIS Sub-Division

\begin{tabular}{|c|l|l|}
\hline $\begin{array}{c}\text { Sub- } \\
\text { Domain } \\
\text { PO }\end{array}$ & \multicolumn{1}{|c|}{ Findings } & \multicolumn{1}{c|}{ Activity } \\
\hline \multirow{5}{*}{$\begin{array}{l}\text { Plan and } \\
\text { Organize }\end{array}$} & $\begin{array}{l}\text { There is a } \\
\text { strategic plan in } \\
\text { using the EMIS } \\
\text { information } \\
\text { system in the } \\
\text { future. }\end{array}$ & $\begin{array}{l}\text { Routine meetings are } \\
\text { held between the EMIS } \\
\text { CEO, Head of IT } \\
\text { Administration, and ME } \\
\text { CIO every month. }\end{array}$ \\
\cline { 2 - 3 } & $\begin{array}{l}\text { There is data } \\
\text { integration in the } \\
\text { EMIS information } \\
\text { system. }\end{array}$ & $\begin{array}{l}\text { The system has been } \\
\text { integrated with the } \\
\text { ministry and related } \\
\text { agencies like Função } \\
\text { Publika, STAE, and } \\
\text { BNU. }\end{array}$ \\
\cline { 2 - 3 } & $\begin{array}{l}\text { There is planning } \\
\text { directed towards } \\
\text { using EMIS } \\
\text { information } \\
\text { system } \\
\text { technology. }\end{array}$ & $\begin{array}{l}\text { A work (architecture) } \\
\text { framework about the } \\
\text { EMIS data processing } \\
\text { process has been } \\
\text { formed in a blueprint. }\end{array}$ \\
\cline { 2 - 3 } & \multicolumn{2}{|c|}{} \\
\hline
\end{tabular}




\begin{tabular}{|c|c|c|}
\hline & $\begin{array}{l}\text { There is } \\
\text { communication of } \\
\text { regulations and } \\
\text { responsibilities } \\
\text { between IT staff } \\
\text { and user staff. }\end{array}$ & $\begin{array}{l}\text { There are monthly staff } \\
\text { meetings led by the } \\
\text { EMIS Staff Heads for } \\
\text { staff regarding the } \\
\text { development of data } \\
\text { processing, regulations, } \\
\text { and obstacles found in } \\
\text { inputting data. }\end{array}$ \\
\hline \multirow{4}{*}{$\begin{array}{l}\text { Acquire } \\
\text { and } \\
\text { Implement }\end{array}$} & $\begin{array}{l}\text { The EMIS CEO } \\
\text { has already done } \\
\text { and developed } \\
\text { feasibility studies } \\
\text { on mistakes that } \\
\text { occur. }\end{array}$ & $\begin{array}{l}\text { There are meetings } \\
\text { between the EMIS CEO } \\
\text { and suppliers about } \\
\text { using the EMIS } \\
\text { application to answer } \\
\text { EMIS information } \\
\text { needs. }\end{array}$ \\
\hline & $\begin{array}{l}\text { There are } \\
\text { divisions and a } \\
\text { number of access } \\
\text { rights for EMIS. }\end{array}$ & $\begin{array}{l}\text { There are divisions of } \\
\text { access rights for the } \\
\text { application like for the } \\
\text { Department Chief, } \\
\text { International Assessor, } \\
\text { Data Collection } \\
\text { Supervisor, and Data } \\
\text { Entry Supervisor. }\end{array}$ \\
\hline & $\begin{array}{l}\text { There is a } \\
\text { conversion of data } \\
\text { or backup data } \\
\text { from the EMIS } \\
\text { information } \\
\text { system. }\end{array}$ & $\begin{array}{l}\text { There is coordination } \\
\text { between the EMIS and } \\
\text { IT parties in the backup } \\
\text { data for the EMIS } \\
\text { server every month. }\end{array}$ \\
\hline & $\begin{array}{l}\text { The controlling is } \\
\text { done directly by } \\
\text { the EMIS staff } \\
\text { over the suppliers. }\end{array}$ & $\begin{array}{l}\text { The controlling is done } \\
\text { directly by the head of } \\
\text { the EMIS staff to } \\
\text { develop the interface, } \\
\text { processes, and database. }\end{array}$ \\
\hline \multirow[b]{2}{*}{$\begin{array}{l}\text { Decision } \\
\text { and } \\
\text { Support }\end{array}$} & $\begin{array}{l}\text { The identification } \\
\text { of education } \\
\text { needs and training } \\
\text { are based on user } \\
\text { needs. }\end{array}$ & $\begin{array}{l}\text { There is training for } \\
\text { users on using the } \\
\text { Internet, MS Office } \\
\text { application programs, } \\
\text { and My SQL database. }\end{array}$ \\
\hline & $\begin{array}{l}\text { Scheduling to } \\
\text { divide tasks is } \\
\text { needed. }\end{array}$ & $\begin{array}{l}\text { There is a division of } \\
\text { access to EMIS staff } \\
\text { users to facilitate } \\
\text { control of input reports } \\
\text { by data collection } \\
\text { supervisors and data } \\
\text { entry supervisors. }\end{array}$ \\
\hline $\begin{array}{l}\text { Monitor } \\
\text { and } \\
\text { Evaluate }\end{array}$ & $\begin{array}{l}\text { There are reports } \\
\text { given to } \\
\text { leadership about } \\
\text { EMIS work } \\
\text { performance } \\
\text { routinely. }\end{array}$ & $\begin{array}{l}\text { There are reports from } \\
\text { the data collection } \\
\text { supervisors and data } \\
\text { entry supervisors given } \\
\text { to leadership about } \\
\text { work performance and } \\
\text { data entry done by } \\
\text { EMIS routinely. }\end{array}$ \\
\hline
\end{tabular}

To reach the maximum goals with help from the COBIT 4.1 guidelines, there are various items that need to be improved in EMIS, which are listed as follows:
Table 11. Findings and Recommendations

\begin{tabular}{|c|c|c|}
\hline Domain & Findings & Recommendations \\
\hline \multirow{4}{*}{$\begin{array}{l}\text { Plan and } \\
\text { Organize }\end{array}$} & $\begin{array}{l}\text { There are no } \\
\text { standards or } \\
\text { standard } \\
\text { guidelines to } \\
\text { control and } \\
\text { manage the IT } \\
\text { management } \\
\text { process. }\end{array}$ & $\begin{array}{l}\text { There needs to be } \\
\text { policies, standards, and } \\
\text { standard regulations to } \\
\text { control, understand, and } \\
\text { manage risks in ME and } \\
\text { especially EMIS. }\end{array}$ \\
\hline & $\begin{array}{l}\text { Fund allocation is } \\
\text { uneven, where } \\
\text { funds are } \\
\text { allocated only in } \\
\text { the EMIS } \\
\text { application } \\
\text { without seeing } \\
\text { the infrastructure, } \\
\text { maintenance, and } \\
\text { knowledge } \\
\text { development of } \\
\text { its human } \\
\text { resources. }\end{array}$ & $\begin{array}{l}\text { There needs to be even } \\
\text { funding priorities in the } \\
\text { EMIS annual budget } \\
\text { that focuses on the } \\
\text { application, } \\
\text { information, } \\
\text { infrastructure, and } \\
\text { knowledge development } \\
\text { of its human resources. }\end{array}$ \\
\hline & $\begin{array}{l}\text { Staff recruitment } \\
\text { is done only to } \\
\text { answer the } \\
\text { criteria that have } \\
\text { been determined, } \\
\text { without looking } \\
\text { at the education } \\
\text { and expertise in } \\
\text { the field. }\end{array}$ & $\begin{array}{l}\text { Staff recruitment and } \\
\text { employee management } \\
\text { must be in accordance } \\
\text { with the field or skill to } \\
\text { achieve accurante and } \\
\text { relevant information. }\end{array}$ \\
\hline & $\begin{array}{l}\text { There is a lack of } \\
\text { expert staff in the } \\
\text { IT sub-division } \\
\text { and EMIS sub- } \\
\text { division in } \\
\text { operating and } \\
\text { using IT. }\end{array}$ & $\begin{array}{l}\text { There needs to be } \\
\text { expert staff in their field } \\
\text { like technical support, } \\
\text { network administrators, } \\
\text { database administrators, } \\
\text { systems analysts, } \\
\text { programmers, and users } \\
\text { to assist and facilitate } \\
\text { the system operational } \\
\text { process and IT use. }\end{array}$ \\
\hline $\begin{array}{l}\text { Acquire } \\
\text { and } \\
\text { Implement }\end{array}$ & $\begin{array}{l}\text { There is a lack of } \\
\text { knowledge } \\
\text { transfer from the } \\
\text { IT staff to the } \\
\text { EMIS division in } \\
\text { retrieval } \\
\text { operations and } \\
\text { processing from } \\
\text { the EMIS } \\
\text { database server } \\
\text { (Sql server 2008). }\end{array}$ & $\begin{array}{l}\text { There needs to be a } \\
\text { transfer of knowledge to } \\
\text { competent staff for data } \\
\text { processing. }\end{array}$ \\
\hline $\begin{array}{l}\text { Deliver } \\
\text { and } \\
\text { Support }\end{array}$ & $\begin{array}{l}\text { There is no } \\
\text { service desk in } \\
\text { the IT division. }\end{array}$ & $\begin{array}{l}\text { There needs to be a } \\
\text { service desk as an } \\
\text { intermediary between } \\
\text { users and the } \\
\text { administrator for } \\
\text { processing and } \\
\text { reporting of all EMIS } \\
\text { information system } \\
\text { activities. }\end{array}$ \\
\hline
\end{tabular}




\begin{tabular}{|l|l|l|}
\cline { 2 - 3 } & $\begin{array}{l}\text { There is a lack of } \\
\text { organization and } \\
\text { control in data } \\
\text { processing } \\
\text { activities. }\end{array}$ & $\begin{array}{l}\text { There needs to be } \\
\text { organization and control } \\
\text { to maximize } \\
\text { productivity and } \\
\text { minimize mistakes. }\end{array}$ \\
\hline \multirow{4}{*}{$\begin{array}{l}\text { Monitor } \\
\text { and } \\
\text { Evaluate }\end{array}$} & $\begin{array}{l}\text { There are no } \\
\text { reviews in the } \\
\text { EMIS work } \\
\text { system. }\end{array}$ & $\begin{array}{l}\text { The work system needs } \\
\text { to be reviewed by EMIS } \\
\text { supervisors. }\end{array}$ \\
\cline { 2 - 4 } & $\begin{array}{l}\text { There are no } \\
\text { internal controls } \\
\text { in activity } \\
\text { evaluations or } \\
\text { resources an } \\
\text { DNPETI. at }\end{array}$ & $\begin{array}{l}\text { There needs to be } \\
\text { internal control in } \\
\text { DNPETI, so that it can } \\
\text { evaluate activities, } \\
\text { infrastructure, and IT } \\
\text { resources. }\end{array}$ \\
\hline
\end{tabular}

There is EMIS information system representation based on COBIT guidelines adjusted with IT activities in information processing and achieving effective and efficient IT management.

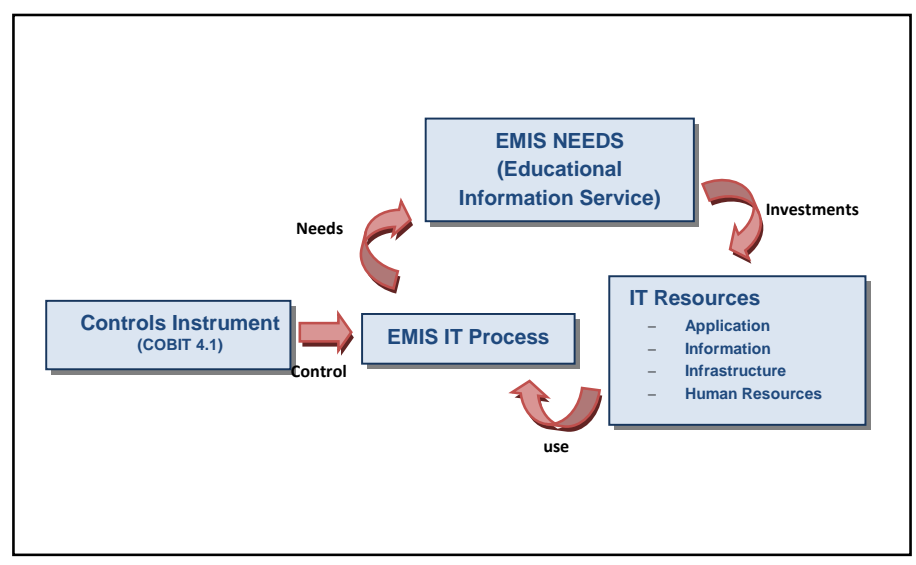

Figure 13. Information Needs Model

Figure 13 above reveals that in providing quality information service to the ME ministry and development partners in East Timor, DNPETI has to be invested in IT resources that consist of:

- The EMIS application is an automatic user system and procedure manual that assists users (EMIS staff) in data processing and providing effective and efficient information. The application that is obtained, whether from the ME ministry or a supplier, must facilitate the job, answer user needs, and be free from human error.

- Information that originates from input data processing (data entry supervisor), processes, and output (data collection supervisor) must answer EMIS needs in providing EMIS information service to the ME ministry and education development partners.

- Infrastructure is related with technology and facilities that assist the EMIS information processing process. DNPETI must provide sufficient infrastructure, starting from the operating system, EMIS application, information processing supporting infrastructure, user comfort, and user safety.

- People comprise knowledge development through expert staff recruitment in their fields. Training is done in turns for information processing users from EMIS staff heads until its staff.

In managing and controlling the current IT resources,
DNPETI needs to have structured IT management to assist the CEO and CIO in EMIS information processing. DNPETI needs to have a particular strategy, whether it is short-term or long-term. The current strategies should be adjusted with an effective and efficient information processing activity.

To reach maximum information results, IT activities in EMIS need to be evaluated by an internal auditing party within the ME ministry. Also, EMIS has to have control standards to improve and reach maximum EMIS goals. Related to this, COBIT is a control instrument that acts as a guideline to help management in managing and understanding risks and advantages related with information and IT. Control over IT activities is done based on the ongoing activities in the EMIS sub-division that are in line with information needs.

\section{CONCLUSION}

Based on the discussion results and analysis of the whole information system process in the EMIS sub-division for using COBIT 4.1, it can be concluded that:

- A review of the COBIT 4.1 process model using maturity levels reveals there is a maturity level for every domain: planning and organization 4.23; acquisition and implementation 4.24; delivery and support 4.23; and monitoring and evaluating 4.42 . The average results are at level 4 , which means in a managed condition.

- The managed condition shows that the DNPETI management team and especially EMIS have implemented procedures that are contained in a domain in COBIT 4.1. This is proven by the CEO and CIO of DNPETI and EMIS in particular have strived to supervise compliance in carrying it out and do continuous intervention if there is a problem in its implementation. However, there are still deficiencies, like EMIS has not established standards or standard guidelines in controlling the information processing, the funds are unevenly distributed, there is a lack of expert staff, the information provided is not appropriate with EMIS needs, and the infrastructure does not support the IT processing process or human resource development as users.

To answer the deficiencies at this time, EMIS needs to apply COBIT 4.1 basic concepts, which can provide clear policies and good IT governance training for ME to help senior management understand and handle risks related with information technology.

\section{REFERENCES}

[1] Kadir A, and Triwahyuni T. Pengenalan Teknologi Informasi. Ed. II - Publisher ANDI Yogyakarta. 2005.

[2] Plano Estratégico de Desenvolvimento, 2011-2030. Versão submetida ao Parlamento Nacional. [Capítulo 2: Capital social. Educação e formação pp. 14-32].

[3] Weber, Ron, 1999, Information Sistem Control and Audit, The University of Queensland: Prentice-Hall Inc

[4] ITGI 2007. COBIT ${ }^{\circledR}$ 4.1. Printed in the United States of America. ISBN 1-933284-72-2.

[5] Maria, E. Fibriani, Charitas; Sinatra, Lina (2012). The Measurement Of Information Technology Performance In Indonesian Higher Education Institutions In The Context Of Achieving Institution Business Goals Using Cobit Framework Version 4.1 ( Case Study : Satya Wacana Christian University, Salatiga)". Researchers World: Journal of Arts, Science \& Commerce, Vol. 3 Issue 3, p9-19. 11p. 
[6] Purwanto, 2010. "Evaluasi Tata Kelola Teknologi Informasi Menggunakan Kerangka Kerja Cobit Dalam Mendukung Layanan Sistem Informasi Akademik (Studi Kasus : Universitas Budi Luhur)”. Jurnal TELEMATIKA MKOM, Vol.2 No.1, ISSN 2085-725X

[7] Software Engineering for Business Information Sistems. (http://id.wikipedia.org/wiki/Sistem_informasi."Definitio n of Application Landscape". Jan 21, 2009. Accessed on January 14, 2011)

[8] Leitch R. dan K. Roscoe Davis, "Accounting Information Sistem”, Prentice-Hall,New Jersey, 1983

[9] Mulyadi, 2002. Auditing, Buku Dua, Edisi VI, Salemba Empat, Jakarta

[10] Weill, P. \& Ross, J. 2006. "IT Governance, How Top Performers Manage IT Decision Rights for Superior Result", Harvard Business School Press, Boston
[11] Budiati A., Ayuning E. 2004. Improving E-government Implementation in Indonesia to Enhance the Government's Capacity to Serve, Unpublished Research Report, MPPM, Department of Management, Monash University, Melbourne

[12] Champlain, Jack, 2003, Auditing Information Sistems, Son-Wiley.

[13] ITGI 2007. COBIT ${ }^{\circledR} 4.1$ Excerpt. Printed in the United States of America.

[14] Djatmiko, Bambang, 2007, Audit Sistem Informasi Untuk Menilai Proses Penyampaian dan Dukungan (Delivery and support) dalam Pelayanan Informasi dengan Menggunakan Framework COBIT (Studi Kasus: PT. Telekomunikasi Indonesia, Tbk. R \& D Center”), Bandung: ITB.

[15] Sugiyono, 2013. Metode Penelitian Pendidikan. Penerbit Alfabeta Bandung. ISBN 979-8433-71-8 